\title{
PENGARUH PELAKSANAAN KEBIJAKAN PEMBINAAN KEPEGAWAIAN DAN DUKUNGAN FASILITAS/SARANA PENDIDIKAN TERHADAP KINERJA PELAYANAN AKADEMIK DAN KOHESIFITAS KELOMPOK PEGAWAI DALAM MEWUJUDKAN PERILAKU BELAJAR DAN PRESTASI BELAJAR MAHASISWA DI STIKES KARSA HUSADA GARUT
}

\author{
1) Andhika Lungguh Perceka \\ ${ }^{1}$ Dosen Program Studi D3 Kebidanan STIKES Karsa Husada Kabupaten Garut. \\ Email: andhikalungguh@yahoo.com, stikeskarsahusada@yahoo.com
}

\begin{abstract}
This study analyzed the number of variables in the environment STIKES Karsa Husada that affect the performance of academic services. The method used is descriptive analysis method with survey techniques. Analysis of the data used is statistical analysis path analysis model (Path Analysis)

The main hypothesis testing results show that the performance Academic Services significantly influence Behavior of Student Learning and Student Achievement in Using Educational Services. An important finding of this study include: 1) Implementation of Personnel Development Policy after the implementation of oversight is not accompanied by follow-up and evaluation and improvement so that policies are conducted no change towards the better. 2) Support Facility Education availability of facilities in support of education is still not, in reviewing the supervision activities will support the facility / facilities not run optimally. 3) Performance Academic Services social skills an employee needs to be improved and excess of information obtained by an employee should be able to support the implementation of activities in STIKes. 4) Employee group cohesiveness, affect how far the positive power of the individual identifying himself to the advancement STIKes involvement. 5) Conduct of Student Learning, Affective showed by the students are still negative mainly for the development and improvement of student learning behavior. 6) Achievement of Student Learning, in non-academic activities, have not increased, so the need is implemented sustainable development.
\end{abstract}

Keywords: Performance Academic, Personal Development, Student Achievement.

\section{A. PENDAHULUAN}

Dalam menghadapi tantangan yang makin berat dalam menghadapi para pesaing penyelenggara pendidikan khususnya Pendidikan Tinggi di bidang kesehatan, yang makin banyak bermunculan di wilayah Kabupaten Garut dalam menyiapkan tenagatenaga ahli kesehatan diantaranya ahli madya keperawatan, ahli madya kebidanan serta perawat professional (S1) yang bermutu, berkualitas dan siap kerja.

STIKes Karsa Husada Garut dalam menjawab tantangan persaingan tersebut, akan mengidentifikasi permasalahan yang ada di STIKes Karsa Husada Garut.

Hal yang pertama di rasa perlu dievaluasi di dalam organisasi STIKes yaitu pelaksanaan kebijakan pembinaaan kepegawaian yaitu belum berjalannya sistem/manajemen STIKes secara baik dan optimal. Peran Seorang Ketua STIKes sebagai figure Pimpinan masih belum dapat dirasakan oleh seluruh sivitas akademika STIKes Karsa Husada Garut, hal ini dikarenakan Ketua STIKes belum dapat menjalankan kewajibannya secara full-time atau belum dapat menjalankan kewajibannya secara penuh waktu dikarenakan kesibukannya 
ditempat lain. Sehingga dalam pembuatan, penentuan dan juga pelaksanaan kebijakan masih banyak ditentukan oleh pihak Yayasan sehingga kemandirian STIKes belum berjalan optimal.

Dalam menjalankan hasil kebijakan yang dibuat, sosialisasi terhadap hasil kebijakan masih belum berjalan optimal. Hal ini dikarenakan sosialisasi kebijakan berupa materi/hasil kebijakan itu sendiri kurang di sosialisasikan kepada sivitas akademika STIKes sehingga pemahaman terhadap materi kebijakan itu sendiri kurang dipahami oleh pegawai, dosen dan juga mahasiswa STIKes sehingga implementasi terhadap waktu pelaksanaan hasil kebijakan itu sendiri berjalan tidak efektif dan efisien.

Masalah lain dalam organisasi STIKes berkaitan dengan pelaksanaan kebijakan pembinaan kepegawaian adalah tenaga pelaksana yaitu tenaga pendidikan. Tenaga pendidikan tidak mendapatkan pembagian tugas yang jelas, fungsi dan penempatan kerja tidak berdasarkan keahlian/latar belakang pendidikan. Fungsi tenaga pendidikan hanya sebatas membantu program studi bukan sebagai tenaga pendidikan STIKes.

Masalah lain sehubungan dengan
pelaksanaan kepegawaian berdasarkan PP 60 Tahun 1999 tentang tata dan laksana Perguruan Tinggi yang berkaitan dengan pelaksanaan kebijakan keuangan. Fungsi keuangan sebagai pelaksanaan kebijakan keuangan yang seharusnya dipegang oleh STIKes sekarang masih dikelola oleh program studi. Pelaksanaan kebijakan tersebut dianggap tidak sesuai dan bertentangan dengan Peraturan Pemerintah karena fungsi program studi hanya merencanakan, menjalankan, mengorganisasikan serta mengontrol kegiatan akademik guna meningkatkan mutu dan kualitas pendidikan. Oleh karena itu fungsi program studi sebagai penyelenggara/ pelaksana kegiatan akademik belum berjalan optimal, efektif dan efisien.

Fenomena masalah kedua yang terjadi di STIKes dalam dukungan fasilitas /sarana pendidikan. Dalam meningkatkan pelayanan khususnya terhadap fasilitas/sarana pendidikan STIKes dihadapkan kepada beberapa masalah diantaranya dalam ketersediaan dana, anggaran yang di berikan belum mencukupi kebutuhan yang ada.

Hal lain masalah yang terjadi pada dukungan fasilitas/sarana pendidikan itu dimensi tenaga kerja, masih belum efektifnya tenaga kerja pelaksana penunjang sarana fasilitas pendikan sehingga dimana saat dibutuhkan sering sekali tidak ada. Adapun faktor lain yang mempengaruhi dimensi dukungan fasilitas/sarana pendidikan yaitu tenaga kerja. Tenaga kerja belum sesuai dengan standar/aturan yang ditetapkan bagian kepegawaian. Hal ini menyebabkan adanya kendala dalam komunikasi dan juga pengetahuan pegawai sehingga menghambat kelancaran dalam bekerja.

Oleh karena itu dalam peningkatan pelayanan terhadap mahasiswa, STIKes terus mengevaluasi, memperbaiki dan menambah fasilitas sarana/fasilitas pendidikan sehingga suasana belajar mengajar dan juga kegiatan akademik menjadi nyaman dan lancar.

Pola-pola pengembangan, pembinaan dan pelatihan dalam meningkatan motivasi pegawai masih kurang dan hanya terbatas pada pejabat/pimpinan saja, kesadaran dalam memberikan kontribusi yang optimal kepada institusi sangat masih jauh dari yang diharapkan. 
Masalah lain dalam kinerja pelayanan akademik dalam dimensi dukungan sosial. Kondisi yang dihadapi di STIKes dapat kita lihat bahwa pegawai belum memiliki hubungan emosional yang tinggi, baik ke sesama pegawai maupun institusi tempat mereka bekerja baik berupa pengakuan, kepercayaan dan bantuan langsung dari pegawai lain belum berjalan optimal.

Faktor lain yang mempengaruhi dimensi kinerja pelayanan akademik yaitu akses terhadap sumber informasi terdapat masalah yang menghambat kinerja pelayanan dengan memperhatikan aspek dalam penguasaan informasi, bahwa kemampuan pengetahuan pegawai dalam mengakses informasi masih rendah kecenderungan menangkap perintah atau tugas hanya garis besarnya saja, sehingga ada kemungkinan pegawai menugaskan atau melempar tugas kepada orang lain. Dengan kondisi ini dapat penulis katakan bahwa pegawai kinerja pelayanan akademik belum berjalan optimal, efektif dan efisien.

Adapun masalah lain yang terjadi sehingga kinerja pelayanan akademik belum dapat berjalan optimal, efektif dan efisien yaitu pembinaan kerja terhadap para pegawai menyangkut peningkatan pengetahuan, peningkatan keterampilan kerja, dan peningkatan masih sangat kurang dan perlu menjadi perhatian lebih dari manajemen STIKes oleh karena perlu di adakan supervisi rutin dan pelatihan-pelatihan yang menyangkut pembinaan kerja pegawai supaya kinerja pelayanan akademik menjadi lebih baik, efektif dan efisien.

Berdasarkan hal tersebut dengan demikian, Kementrian Pendidikan Nasional akan menerapkan standar kompetensi tenaga kependidikan yang berhubungan dengan 1) proses pembelajaran 2) pengembangan potensi, 3) penguasaan akademik. Pengembangan standar kompetensi tenaga pendidikan diarahkan pada peningkatan kualitas tenaga pendidik dan pola pembinaan tenaga pendidik yang terstruktur dan sitematis.

Kompetensi diartikan sebagai pengetahuan, keterampilan, dan nilai-nilai dasar yang direfleksikan dalam kebiasaan berpikir dan tindak dengan demikian, kompetensi yang dimiliki oleh setiap tenaga pendidik akan menunjukkan kualitas tenaga pendidik yang sebenarnya.

Kepemilikan kompetensi tersebut diatas oleh tenaga pendidik akan lebih berkembang manakala didukung oleh iklim organisasi dalam hal ini organisasi perguruan tinggi tempat mereka bekerja yang kondusif. Hal lainnya untuk dapat mencapai tujuan pendidikan yang diharapkan adalah adanya kedekatan dan keterkaitan antara tenaga pendidik yang satu dengan tenaga pendidik lain dengan semangat dan kekompakan dalam kelompok tenaga pendidik. Khususnya mereka yang sama-sama mengajar di satu perguruan tinggi. Kelompok ini akan efektif jika terdapat kohesivitas yang merupakan faktor utama dari keberadaan kelompok.

Adanya kohesivitas yang tinggi pada kelompok tenaga pendidik dan didukung oleh kompetensi professional serta perbaikan iklim perguruan tinggi akan memberikan harapan dan optimisme baru kepada siapapun yang menaruh perhatian kepada dunia pendidikan. Terutama peningkatan prestasi belajar mahasiswa, baik prestasi akademik dan non akademik yang diperoleh mahasiswa dalam pendidikan formal di perguruan tinggi.

Setiap mahasiswa pada prinsipnya tentu berhak memperoleh peluang untuk mencapai kinerja akademik (academic 
performance) yang memuaskan. Namun pada kenyataan sehari-hari tampak jelas bahwa mahasiswa itu memiliki perbedaan dalam hal kemampuan intelektual, kemampuan fisik, latar belakang keluarga, kebiasaan dan pendekatan belajar yang terkadang sangat mencolok antara seorang mahasiswa dengan mahasiswa lainnya.

Sementara itu, fenomena akan menurunnya prestasi belajar mahasiswa baik prestasi akademik maupun non akademik, selain disebabkan oleh faktor-faktor tersebut diatas juga banyak pakar bidang pendidikan dan psikologi yang mencoba mengidentifikasi faktor-faktor penyebab lainnya. Karena pengaruh faktor-faktor tersebut diatas, muncul mahasiswa yang berprestasi tinggi (high achivers) dan berprestasi rendah (under achievers) atau gagal sama sekali. Dalam hal ini keterlibatan semua pihak mulai dari dosen, staff, dan semua pegawai serta orang tua mahasiswa perilaku belajar diharapkan mampu mengantisipasi kemungkinankemungkinan menurunnya prestasi belajar mahasiswa.

\section{B. KAJIAN TEORETIS}

\section{Manajemen SDM}

Manajemen sumber daya manusia merupakan bagian dari ilmu manajemen, yang berarti merupakan suatu usaha untuk mengarahkan dan mengelola sumber daya manusia di dalam suatu organisasi agar mampu berfikir dan bertindak sebagaimana yang diharapkan organisasi. Organisasi yang maju tentu dihasilkan oleh personil/pegawai yang dapat mengelola organisasi tersebut ke arah kemajuan yang diinginkan organisasi, sebaliknya tidak sedikit organisasi yang hancur dan gagal karena ketidakmampuannya dalam mengelola sumber daya manusia.
Menurut Hasibuan (2001 :10) manajemen sumber daya manusia adalah “ Ilmu dan seni mengatur hubungan dan peranan tenaga kerja agar efektif dan efisien, membantu terwujudnya tujuan perusahaan, karyawan dan masyarakat ". Sedangkan menurut Simamora (2004 : 4) manajemen sumber daya manusia adalah ," pendayagunaan, pengembangan, penilaian, pemberian balas jasa, dan pengelolaan individu anggota organisasi atau kelompok karyawan, juga menyangkut desain dan implementasi sistem perencanaan, penyusunan karyawan, pengembangan karyawan, pengelolaan karir, evaluasi kinerja, kompensasi karyawan dan hubungan ketenagakerjaan yang baik.

\section{Administrasi Negara}

Manajemen sumber daya manusia merupakan bagian dari ilmu manajemen, yang berarti merupakan suatu usaha untuk mengarahkan dan mengelola sumber daya manusia di dalam suatu organisasi agar mampu berfikir dan bertindak sebagaimana yang diharapkan organisasi. Organisasi yang maju tentu dihasilkan oleh personil/pegawai yang dapat mengelola organisasi tersebut ke arah kemajuan yang diinginkan organisasi, sebaliknya tidak sedikit organisasi yang hancur dan gagal karena ketidakmampuannya dalam mengelola sumber daya manusia.

Menurut Hasibuan (2001 :10) manajemen sumber daya manusia adalah “ Ilmu dan seni mengatur hubungan dan peranan tenaga kerja agar efektif dan efisien, membantu terwujudnya tujuan perusahaan, karyawan dan masyarakat “. Sedangkan menurut Simamora (2004 : 4) manajemen sumber daya manusia adalah ," pendayagunaan, pengembangan, penilaian, pemberian balas jasa, dan pengelolaan individu anggota organisasi atau kelompok 
karyawan, juga menyangkut desain dan implementasi sistem perencanaan, penyusunan karyawan, pengembangan karyawan, pengelolaan karir, evaluasi kinerja, kompensasi karyawan dan hubungan ketenagakerjaan yang baik.

\section{Pembinaan Ketengaaan}

Pembinaan kerja terhadap para pegawai atau petugas oleh para lembaga yang mempekerjakannya, sangatlah diperlukan sebagaimana dikemukakan oleh Iskandar (2003/b:257) yaitu untuk :

“ Meningkatkan kualitas sumber daya manusia agar petugas itu dapat bekerja secara efektif, efesien dalam lingkup tugas yang dibebankan kepadanya. Dimana paling sedikit ada tiga aspek pada diri pegawai yang memberikan pembinaan, yaitu peningkatan sikap pegawai terhadap pelaksanaan tugas pekerjaannya ".

Pelaksanaan kebijakan pembinaan kepegawain dapat dilihat dari berbagai dimensi dan indikator seperti halnya dikemukakan oleh Dunn (1999:32) yaitu sosialisasi kebijakan, pelaksana serta pengendalian.

\section{Sarana Prasaranan Pendidikan}

PP RI No. 19 tahun 2007, Permendiknas No.24 Tahun 2007, dan Pedoman Penyelenggaraan Pendidikan Peguruan Tinggi, sebagai kebijakan yang mengatur tentang sarana prasana yang harus disediakan perguruan tinggi, telah sesuai dengan teori. Baik dalam teori maupun kebijakan, dinyatakan bahwa perguruan tinggi harus menyediakan sarana prasarana umum yang lengkap dan juga sarana prasarana khusus yang dapat membantu proses kegiatan belajar mengajar di perguruan tinggi.
Pada kenyataannya, sarana dan prasarana umum yang disediakan di sebagian besar perguruan tinggi (delapan dari sembilan perguruan tinggi) telah cukup lengkap dan sesuai dengan teori maupun kebijakan. Akan tetapi, dalam aspek penyediaan dan pemanfaatan sarana prasarana khusus, masih terdapat ketidaksesuaian antara pelaksanaan dengan teori dan kebijakan. Ini karena, secara umum, perguruan tinggi masih menyediakan sarana prasarana khusus yang sangat terbatas. Bahkan ada perguruan tinggi yang tidak memiliki sarana prasarana khusus bagi mahasiswa. Pada beberapa perguruan tinggi, pemanfaatan sarana prasarana khusus yang telah disediakan juga masih terbatas karena ketidaktahuan pegawai.

\section{METODE PENELITIAN}

Metode yang digunakan adalah metode Survey Explanasi, (Burhan Bungin,2007) dengan tujuan menjelaskan fenomena sejumlah pengaruh dari variabel bebas terhadap variabel tidak bebas. Analisis data dalam rangka uji hipotesis menggunakan Analisis Jalur (Path Analysis) , Supranto (1997)..

\section{HASIL DAN PEMBAHASAN}

\section{Permasalahan Pendidikan Di STIKes Karsa Husada Garut}

Banyak faktor yang mempengaruhi kemajuan Perguruan Tinggi diantaranya adalah pimpinan Perguruan Tinggi/Rektor karena Perguruan Tinggi akan memiliki performa terbaik jika dipimpin oleh seorang rektor yang kuat, visioner, konsisten, demokratis, dan berani mengambil keputusankeputusan strategis. Agar STIKes menjadi Perguruan Tinggi yang memiliki performa terbaik maka manajmen STIKes harus mampu merekrut calon pemimpin yang mampu memanejerial organisasi Perguruan Tinggi yang akan dipimpinnya. 
Berdasarkan hasil wawancara dengan praktisi pendidikan di STIKes yang menanggapi tentang perkembangan pendidikan untuk jenjang pendidikan tinggi, dihadapkan pada kenyataan bahwa pertama banyak lulusan STIKes yang tidak melanjutkan pendidikannya ke pendidikan tinggi dengan alasan mencari lapangan pekerjaan sehingga banyak yang bekerja. Faktor kedua adalah wilayah dimana penduduk yang berpendidikan tinggi lebih banyak di daerah perkotaan dibanding dengan penduduk di daerah pedesaan, hal ini dapat dimaklum karena perguruan tingginya itu sendiri berada di daerah perkotaan. Selain dari kedua faktor diatas faktor lain yang merupakan wacana mengemuka didalam masyarakat dan banyak dikeluhkan adalah besarnya biaya pendidikan pada jenjang pendidikan tinggi. Berdasarkan ketiga faktor tersebut menyebabkan pendidikan tinggi di STIKes menjadi pendidikan yang tidak tersentuh dan hanya mampu dinikmati oleh sebagian kecil masyarakat yang berkemampuan secara ekonomi.

Hal lain yang juga merupakan permasalahan pendidikan di STIKes adalah jumlah Dosen yang tidak merata pada setiap jenjang satuan pendidikan terutama pada tiaptiap Program Studi di STIKes. Selain itu

\section{Kebijakan Strategis Dalam Pembinaan Pendidikan Di STIKes Karsa Husada Garut}

Visi STIKes Karsa Husada Garut yaitu Sekolah Tinggi Ilmu Kesehatan Karsa Husada Garut menjadi lembaga pendidikan yang bermutu dalam penyelenggaraan tri dharma peguruan tinggi bidang kesehatan serta mampu bersaing di tingkat regional dan nasional pada tahun 2015. Adapun misi STIKes Karsa Husada Garut adalah sebagai berikut : persebaran jumlah mahasiswa yang tidak merata rasio antara mahasiswa dan Dosen belum seimbang. Berdasarkan hal tersebut penulis beranggapan bahwa kinerja Dosen akan lebih maksimal apabila terdapat pembagian/persebaran mahasiswa yang merata sehingga dalam proses belajar akan lebih maksimal dan juga faktor upah/gaji akan berpengaruh pada kinerja Dosen itu sendiri.

Selain kedua permasalahan diatas yang juga dapat berpengaruh pada mutu pendidikan STIKes adalah profesionalisme Dosen yang dapat ditunjang dengan latar belakang pendidikan dosen itu sendiri. Berdasarkan hasil temuan penulis masih penulis temukan masih ada dosen yang mengajar di STIKes mengajar matakuliah yang tidak sesuai dengan latar belakang pendidikan yang dimiliki oleh oleh Dosen itu sendiri. Berdasarkan hal tersebut penulis berasumsi bahwa dengan latar belakang yang tidak sesuai dengan mata kuliah yang diajarkan kepada mahasiswa dan juga bukan dari latar belakang pendidikan yang bukan dari keguruan dapat berpengaruh kepada perilaku belajar itu sendiri sehingga kemampuan mengajarnya pun kurang professional dibandingkan dengan mereka yang berlatar belakang pendidikan dari keguruan.

a. Mengembangkan kurikulum pendidikan yang berorientasi kepada kebutuhan masyarakat dan pengembangan ilmu pengetahuan dan teknologi bidang kesehatan.

b. Menciptakan proses belajar mengajar yang kondusif dan inovatif.

c. Menyelenggarakan penelitian yang dapat meningkatkan keunggulan di bidang pengetahuan dan teknologi kesehatan.

d. Menyelenggarakan pengabdian masyarakat dalam bidang kesehatan. 
e. Mengembangkan kemitraan dengan berbagai institusi pengguna baik regional maupun nasional.

Dalam rangka mencapai visi dan misi tersebut, maka STIKes Karsa Husada Garut berupaya melakukan pengembanganpengembangan dalam meningkatkan proses belajar mengajar yang berkualitas guna menciptakan tenaga kesehatan yang professional dan berkualitas dalam bentuk Rencana Induk Pengembangan (RIP) / Rencana Strategis (Renstra). Rencana Induk Pengembangan STIKes Karsa Husada Garut meliputi perencanaan pengembangan pendidikan, perencanaan pengembangan tenaga Dosen, perencanaan pengabdian masyarakat dan perencanaan sarana serta prasarana pendidikan.

Rencana Pengembangan Induk STIKes Karsa Husada Garut ini merupakan Adapun didalam RIP ini terdapat halhal sebagai berikut :

\section{Kebijakan Dasar}

\section{Kebijakan Umum}

Pengembangan STIKes Karsa Husada Garut merupakan bagian yang tidak dapat Untuk dapat mencapai itu semua maka perlu adanya pengembangan sumber daya manusia salah satunya adalah melalui pendidikan tinggi, dimana dalam pendidikan pelaksanaan pendidikannya akan selalu mengacu pada peraturan perundangan yang berlaku bagi pendidikan di Indonesia.

\section{Kebijakan Khusus}

Pengembangan STIKes Karsa Husada Garut dimaksudkan untuk :

- Ikut serta dalam pembangunan nasional terutama dalam pegangan dalam pendukung dan pelaksanaan pembangunan nasional. Rencana Pengembangan Induk 5 (lima) tahun ini dirumuskan dengan mempertimbangkan berbagai peluang serta tantangan yang sedang dan akan terjadi selama kurun waktu 5 tahun mendatang dalam bidang keilmuan, perkembangan teknologi dan industri, serta perubahan-perubahan social, ekonomi, dan politik di Indonesia serta di Dunia.

Rencana Induk Pengembangan (RIP) 5 tahun ini ditujukan kepada segenap warga untuk menjadi pegangan dalam usaha untuk mencapai tujuan STIKes Karsa Husada Garut. Rencana Induk Pengembangan (RIP) ini dimaksud sebagai pedoman dasar dari arah pengembangan kegiatan pendidikan yang diselenggarakan, beserta sarana dan prasarana yang menyertainya.

pengembangan Sumber Daya Manusia.

- Melaksanakan Program Pendidikan dengan tujuan meningkatkan daya piker secara analisis, strategis dalam menghadapi permasalahan empiris dan praktek kerja.

- Memenuhi kebutuhan pasar kerja yang terampil dan mandiri dalam melaksanakan tugas-tugasnya.

- STIKes Karsa Husada garut sebagai lembaga pendidikan tinggi yang senantiasa memperhatikan kepentingan masyarakat dan pasar kerja melalui penelitian dan pengabdian masyarakat.

- Sebagai wadah bagi lulusan SMU yang ingin mengembangakan dirinya untuk mencapai karier yang lebih baik.

\section{Dasar Perencanaan}




\section{Tujuan Perencanaan}

a. Menyempurnakan

pendidikan sehingga mendapatkan hasil yang optimal.

b. Meningkatkan pengabdian kepada masyarakat Kabupaten Garut khususnya dan Jawa Barat pada umumnya.

c. Meningkatkan kerjasama dengan Perguruan Tinggi sejenis di Jawa Barat khususnya dan Indonesia pada umumnya, maupun instansi pemerintah atau instansi swasta lainnya.

d. Untuk mendapatkan pedoman yang jelas tentang pelaksanaan pengembangan sebagai landasan kerja sivitas akademika STIKes Karsa Husada Garut.

\section{Strategi Perencanaan}

Dalam menyusun Rencana Induk Pengembangan (RIP) STIKes Karsa Husada Garut ini dipandang perlu memperhatikan halhal yang didahulukan dalam penanganannya (skala prioritas), sehingga dapat diperoleh manfaat yang sebesar-besarnya. Perencanaan ini disusun atas dasar kemapuan (dana) yang dimiliki STIKes Karsa Husada Garut baik yang bersifat peningkatan SDM dan penambhan sarana dan prasarana sehingga dapat digunakan sebagai pedoman kerja, hal ini meliputi :
a. Penambahan SDM dan peningkatan kualitas SDM yang sudah ada.
b. Penambahan sarana dan prasarana.

\section{Lingkup Perencanaan}

Lingkup perencanaan ini meliputi :
a. Bidang Pendidikan
b. Bidang Pengabdian Masyarakat
c. Bidang Pengembangan Sumber Daya Manusia
d. Bidang Pengembangan Sarana dan Prasarana

\section{Kondisi Internal dan Eksternal \\ 1. Kondisi Internal}

STIKes Karsa Husada Garut akan memiliki kekuatan-kekuatan yang harus dikembangkan semaksimal mungkin dan kelemahan-kelemahan yang perlu dibenahi untuk menghadapi masa mendatang. kekuatan dan kelemahan tersebut mencakup berbagai aspek antara lain sumber daya, keilmuan, tridharma, sarana-prasarana, dukungan organisasi dan manajemen serta kerjasama.

\subsection{Kekuatan}

a. Tersedianya kuantitas tenaga dosen di lingkungan akademi yang cukup

b. Tersedianya saran dan prasarana pendidikan yang cukup

c. Lokasi pendidikan yang strategis

\subsection{Kelemahan}

a. Tingkat sosial ekonomi masyarakat yang rendah, sehingga menyebabakan input akademi kurang

b. Alat-alat praktek laboratorium tertentu sangat mahal (import) sehingga menyebabkan daya beli akademi untuk mengembangkan laboratorium kurang.

c. Buku-buku sumber sangat mahal (import) sehingga akan menghambat pengembangan akademi.

\section{Kondisi Eksternal}

Ada beberapa peluang dan ancaman/tantangan yang perlu diperhatikan oleh STIKes Karsa Husada Garut. Peluang dan tantangan tersebut meliputi aspek kependudukan, ipoleksosbud, peraturan perundangan, teknologi, persaingan dengan perguruan tinggi lain, kualitas calon mahasiswa dan lingkungan sekitar.

\subsection{Peluang}

a. Keterbukaan privatisasi/swastanisasi bidang pendidikan kesehatan 
b. Keterbukaan kompetensi institusi pendidikan kesehatan

c. Kebutuhan tenaga kesehatan yang cukup tinggi

d. Animo masyarakat masuk pendidikan kesehatan cukup tinggi

\subsection{Tantangan}
a. Keadaan ekonomi yang belum membaik
b. Keterbukaan untuk jenjang lanjut pendidikan kesehatan didalam maupun luar negeri.

\section{Rencana Induk Pengembangan STIKes Karsa Husada Garut}

\section{Pengembangan Pendidikan}

Strategi pengembangan pendidikan STIKes Karsa Husada garut mencakup sistem pengajaran, proses belajar mengajar, serta sarana prasarana, yakni:

a. STIKes Karsa Husada garut menyelenggarakan pendidikan tinggi yang memberikan kemampuan untuk melakukan pekerjaan dan mampu melakukan pengembangan pengetahuan dalam bidangnya,

b. Peninjauan kurikulum pendidikan yang menunjang terhadap tuntutan kebutuhan masyarakat dan pengetahuan serta teknologi bidang kesehatan setiap 2 (dua) tahun.

c. Peningkatan dan pengembangan system dan metode pendidikan untuk dapat menghasilkan lulusan secara efisien dan efektif.
d. Peningkatan kualitas pendidikan kesehatan untuk mendukung kebutuhan pembangunan.

\section{Pengembangan Pengabdian Masyarakat}

Strategi pengembangan pengabdian pada masyarakat meliputi pelayanan dan kerjasama :

a. STIKes Kars Husada garut
melaksanakan pengabdian pada masyarakat yang berguna bagi masyarakat atas dasar ilmu pengetahuan yang dikembangkan secara terus menerus.

b. Peningkatan pelayanan untuk membantu masyarakat dengan berbagai bidang yang diperlukan serta meningkatkan kemampuan, dinamika dan peran serta masyarakat untuk membangun masyarakat sehat.

c. Pengembangan kerjasama dengan pihak-pihak yang membutuhkan, baik pihak swasta, pemerintah di dalam Negeri.

\section{Pengembangan Sumber Daya Manusia}

Pembangunan dan peningkatan kualitas sivitas akademika dengan pembentukan sikap, moral dan etika. Pengembangan iklim kerja, budaya akademik, kompetisi ilmiah, keahlian dan keterampilan dikalangan sivitas akademika .

\section{Strategi Pengembangan Sarana dan Prasarana}

Sarana dan prasarana yang meliputi bangunan gedung (pendidikan, penelitian, perkantoran, dan penunjang), peralatan perabotan, jaringan (jalan, listrik, telpon, air, internet, buangan dan limbah), pertamanan dan kebun akan dikembangkan sesuai dengan lingkungan kawasan kota dan wilayah dengan

a. Peningkatan kualitas sarana dan prasarana yang menunjang dalam proses belajar mengajar.

b. Pembangunan sarrana dan prasarana yang menunjang terciptanya keamanan, ketertiban, kelancaran dan kemudahan.

c. Penciptaan citra kampus yang indah, sejuk, nyaman dan tentram dalam menunjang iklim belajar mengajar. 
d. Penataan ruangan yang efisien dan efektif dalam wujud satu perencanaan tata ruang kampus.

\section{Tugas Pokok dan Fungsi STIKes Karsa Husada Garut Dalam Pembinaan Pendidikan}

Bentuk-bentuk dan tugas pembinaan tersebut sangat ditentukan oleh upaya pembinaan STIKes Karsa Husada Garut yang dilaksankan untuk membentuk manusia Indonesia seutuhnya, (Saiduin,A. 2005). Oleh karena itu, bentuk dan tugas pembinaan di STIKes diarahkan agar mencapai sasaran sebagai berikut :

1. Terwujudnya kondisi dinamis yang menunjang peningkatan mutu pendidikan.

2. Terwujudnya kondisi yang dapat mendorong ke arah berkembangnya pikiran ilmiah.

3. Terwujudnya kondisi yang memungkinkan setiap warga Negara pada usia pendidikan dalam berbagai strata untuk menikmati pendidikan, menjadi cerdas, dan terampil dalam ikatan pemenuhan kewajiban belajar, Adapun ruang lingkup pembinaan STIKes Karsa Husada Garut antara lain:
a. Mengupayakan pelaksanaan kurikulum berbasis kompetensi (KBK).

b. Mengupayakan kemandirian manajemen dan pembiyaan pendidikan yang didikung oleh swadaya masyarakat.

c. Efektifitas, pelaksanaan kurikulum dan pengembangannya, kegiatan pembelajaran dan penyelenggaraan administrasi .

d. Meningkatan peran STIKes Karsa Husada Garut dalam gerakan peningkatan perilaku, prestasi, keimanan, ibadah dan akhlak mulia.

e. Memenuhi kekurangan ketenagaan dan meningkatkan mutu ketenagaan.

f. Meningkatkan pengadaan dan pemanfaatan sarana dan prasarana pendidikan

g. Menciptakan hubungan yang harmonis antara STIKes Karsa Husada Garut dengan lingkungannya Meningkatan peran aktif STIKes Karsa Husada Garut dalam gerakan pengabdian masyarakat

h. Menciptakan dan meningkatan hubungan kerjasama dengan instansi lain.

\section{Karakteristik Responden Berdasarkan Usia}

Karakteristik responden berdasarkan usia diklasifikasikan dalam beberapa kelompok usia, seperti disajikan dalam tabel berikut :

Tabel .1

Karakteristik Responden Berdasarkan Usia

\begin{tabular}{|l|c|c|c|c|c|}
\hline \multirow{2}{*}{ No } & \multirow{2}{*}{$\begin{array}{c}\text { Usia } \\
\text { (Tahun) }\end{array}$} & $\begin{array}{c}\text { Dos } \\
\text { en }\end{array}$ & $\begin{array}{c}\text { Pegawai } \\
\text { rangkap } \\
\text { Dosen }\end{array}$ & \multirow{2}{*}{ Jmlh } & $\%$ \\
\cline { 3 - 6 } & & 6 & 3 & 9 & 25,72 \\
\hline 1. & $<30$ & 4 & 0 & 4 & 11,43 \\
2. & $31-34$ & 5 & 1 & 6 & 17,14 \\
3. & $35-39$ & 5 & 2 & 8 & 22,85 \\
4. & $40-44$ & 6 & 2 & 6 \\
5. & $45-49$ & 2 & 0 & 6 & 17,14 \\
6. & $>50$ & 5 & 1 & 35 & 100 \\
\hline \multicolumn{7}{|c|}{ Jumlah } & 28 & 7 & & \\
\hline
\end{tabular}

Sumber: Hasil penelitian 2010

Berdasarkan data dalam tabel 4.1 diatas terlihat bahwa usia responden yang paling banyak berada pada usia antara $<30$ tahun, dengan persentase sebesar $25,72 \%$ dan persentase terkecil pada usia responden antara 45-49 tahun. Hal ini menunjukan bahwa sebagian responden berada pada usia yang cukup matang serta cukup berpengalaman dalam tugasnya. Sehingga kemampuan dalam 
mengambil keputusan dan menjawab pertanyaan cukup tinggi.

\section{Karakteristik Responden Berdasarkan Tingkat Pendidikan}

Hasil penelitian menunjukan karakteristik responden berdasarkan tingkat pendidikan adalah sebagaimana disajikan pada tabel sebagai berikut:

Tabel.2 Karakteristik Responden Berdasarkan Tingkat Pendidikan

\begin{tabular}{|c|c|c|c|}
\hline No & Tingkat Pendidikan & Frekuensi & \% \\
\hline 1 & Sekolah Dasar & 0 & 0 \\
\hline 2 & SMP/Sederajat & 0 & 0 \\
\hline 3 & SMA/Sederajat & 0 & 0 \\
\hline 4 & Diploma & 4 & 11,43 \\
\hline 5 & Sarjana & 26 & 74,29 \\
\hline 6 & Master & 5 & 14,28 \\
\hline \multicolumn{2}{|c|}{ Jumlah } & 35 & 100 \\
\hline
\end{tabular}

Sumber: Hasil Penelitian 2010

Berdasarkan Tabel. 2 diatas menunjukan bahwa persentase terbesar $(74,29 \%)$ dari responden berpendidikan Strata satu (S-1) dan sederajat yaitu sebanyak 26 orang, sedangkan persentase tekecil adalah responden yang berpendidikan Diploma/Sederajat hanya bejumlah 4 orang $(11,43 \%)$, responden yang berpendidikan Sekolah Dasar ternyata tidak ada, adapun responden yang berpendidikan SMP/Sederajat tidak ada, SMA/Sederajat tidak ada, dan Master (14,28\%). Dari data

\section{E. SIMPULAN DAN REKOMENDASI}

Berdasarkan hasil penelitian dapat ditarik kesimpulan bahwa rata-rata jawaban responen pada variabel Pelaksanaan Kebijakan Pembinaan Kepegawaian adalah baik, dengan indikator persentase tertinggi ada pada dimensi sosialisasi, yaitu mengenai "Materi dan Tenaga Pelaksana", sedangkan persentase terendah terdapat pada dimensi Pengendalian, yaitu mengenai "Pengawasan dan Tindak Lanjut". Selanjutnya adalah rata- tersebut menunjukan bahwa sebagian besar responden pendidikannya relatif tinggi, sehingga peneliti dapat menyatakan bahwa reponden dapat mengerti dan memahami item pertanyaan dalam kuisioner sehingga dapat memberikan jawaban yang sesuai dengan apa yang mereka ketahui.

Karakteristik responden berdasarkan pekerjaan/jabatannya dapat dilihat dari tabel dibawah ini:

Tabel.3

Karakteristik Responden Berdasarkan Pekerjaan/Jabatan

\begin{tabular}{|c|c|c|c|}
\hline No & Pekerjaan/Jabatan & Jmlh & $\%$ \\
\hline 1 & Ketua & 1 & 2,86 \\
\hline 2 & Pembantu Ketua & 3 & 8,57 \\
\hline 3 & Ka Prodi & 3 & 8,57 \\
\hline 4 & Dosen tetap & 20 & 57,14 \\
\hline 5 & $\begin{array}{l}\text { Pegawai yang juga } \\
\text { sebagai dosen }\end{array}$ & 8 & 22,86 \\
\hline & Jumlah & 35 & 100 \\
\hline
\end{tabular}

Sumber: Hasil Penelitian 2010

Berdasarkan tabel diatas dapat diketahui bahwa semua responden memiliki peran dan fungsi yang berbeda-beda sesuai dengan kewajiban dan tanggung jawabnya masingmasing. Dengan jumlah responden sebanyak yaitu 35 orang responden diatas merupakan responden yang terlibat langsung dalam kegiatan proses belajar mengajar di STIKes Karsa Husada Garut sehingga dapat menunjang terhadap pengumpulan informasi dalam penelitian ini.

rata jawaban responden pada variabel Dukungan Fasilitas/Sarana Pendidikan adalah baik, dengan indikator yang memiliki nilai persentase tertinggi terdapat pada dimensi Tenaga Kerja, yaitu "Monitoring", sedangkan persentase terendah juga terdapat pada dimensi Fasilitas/Sarana dan Tenaga Kerja, yaitu mengenai "Ketersediaan Fasilitas dan Supervisi.

Sedangkan Rata-rata jawaban responden pada variabel Kinerja Pelayanan 
Akademik adalah baik, dengan indikator yang memiliki nilai persentase tertinggi ada pada dimensi Motivasi, yaitu mengenai "Pemuas/Instrinsic Motivation", sedangkan persentase terendah terdapat pada dimensi Dukungan Sosial dan Akses Terhadap Sumber Informasi, yaitu mengenai "Keterampilan Sosial dan Kelebihan Informasi". Sementara itu rata-rata jawaban responden pada variabel Kohesifitas Kelompok Pegawai adalah baik, dengan indikator dengan persentase tertinggi terdapat pada dimensi Kebutuhan Interpersonal, yaitu mengenai "Inklusi", sedangkan persentase terendah terdapat pada dimensi Kebutuhan Interpersonal. yaitu mengenai "Afeksi".

Selanjutnya adalah rata-rata jawaban responden pada variabel Perilaku Belajar Mahasiswa adalah baik, dengan indikator yang memiliki nilai persentase tertinggi terdapat pada dimensi Proses, yaitu mengenai "Refleks", sedangkan persentase terendah terdapat pada dimensi Hasil, yaitu mengenai "Aspek Afektif.

Sedangkan Rata-rata jawaban responden pada variabel Prestasi Belajar Mahasiswa adalah baik, dengan indikator yang memiliki nilai persentase tertinggi ada pada dimensi Akademik, yaitu mengenai "Hasil UAS", sedangkan persentase terendah terdapat pada dimensi Non Akademik, yaitu mengenai "Kegiatan ekstrakulikuler".

Kesimpulan pengujian hipotesis utama menunjukan bahwa Pelaksanaan Kebijakan Pembinaan Kepegawaian dan Dukungan Fasiltas/Sarana Pendidikan berpengaruh secara nyata terhadap variabel Kinerja Pelayanan Akademik dan Kohesifitas Kelompok Pegawai Dalam Mewujudkan Perilaku Belajar Dan Prestasi Belajar Mahasiswa, selanjutnya hasil pengujian subsub hipotesis menunjukan bahwa Secara simultan dan parsial semua variabel tidak memberikan pengaruh yang signifikan.
Sementara itu terdapat hubungan korelasional yang cukup signifikan antar variabel bebas, selanjutnya terdapat korelasional yang kurang signifikan antar variable antara dan terikat.

Beberapa temuan masalah lainnya yang berkaitan dengan penelitian ini adalah sebagai berikut:

Pertama, pada variabel Pelaksanaan Kebijakan Pembinaan Kepegawaian setelah dilaksanakannya Pengawasan tidak dibarengi tindak lanjut dan evaluasi serta perbaikan sehingga kebijakan yang dilaksankan tidak ada perubahan kearah yang lebih baik.

Kedua, pada variabel Dukungan Fasilitas/Sarana Pendidikan ketersediaan fasilitas dalam menunjang pendidikan dirasa masih kurang dan perlu ditambah, dan kegiatan supervisi dalam meninjau akan adanya dukungan fasilitas/sarana belum berjalan optimal.

Ketiga, pada variable Kinerja Pelayanan Akademik keterampilan sosial seorang pegawai masih harus ditingkatkan dan kelebihan Informasi yang didapat oleh pegawai hendaknya dapat menunjang terhadap pelaksanaan kegiatan di STIKes.

Keempat, pada variabel Kohesifitas Kelompok Pegawai, afeksi sejauhmana kekuatan yang positif dari individu dalam mengidentifikasikan keterlibatan dirinya untuk kemajuan STIKes.

Kelima, pada variabel Perilaku Belajar Mahasiswa, Afektif yang ditunjukkan oleh mahasiswa masih bersifat negatif terutama terhadap pengembangan dan peningkatan perilaku belajar mahasiswa.

Keenam, pada variabel Prestasi Belajar Mahasiswa, dalam kegiatan non akademik mahasiswa belum mengalami peningkatan, sehingga perlu dilaksanaan pembinaan yang berkesinambungan.

Implikasi dari hasil penelitian ini adalah kurangnya koordinasi pimpinan dan bawahan dalam pelaksanaan tugas, laporan 
yang dibuat tidak dikaji dan dievaluasi oleh pimpinan sehingga pelayanan yang prima kepada mahasiswa menjadi terhambat, dan

\section{F. REFERENSI}

Anwar, Saifudin. 2005, Sikap Manusia (Teori dan Pengukurannya). Pustaka Pelajar Jogjakarta

Bungin, Burhan, 2007, Penelitian Kualitatif: Komunikasi, ekonomi, Kebijakan Publik dan Ilmu sosial lainnya. Kencana Prenada Media Group, Jakarta

Dunn, William, N. 1999, Analisis Kebijakan Publik, Penyadur Muhajirin Darwin, Hanindita Graha Widya, Jakarta

Fattah, Nanang, 2004, Landasan Manajemen Pendidikan, PT Remaja Rosdakarya, Bandung.

Hasibuan, Malayu SP, 2006, Manajemen Dasar: Pengertian dan Masalah, Bumi Aksara, Jakarta

Iskandar , Jusman, 2003a, Kapita Selekta administrasi Negara dan Kebijakan Publik. Puspaga. Bandung

Simamora, 2004. Administrasi Negara. Jakarta: LP3ES, Jakarta.

Supranto, Bambang, 1997, Statistik Terapan, Rineka Cipta, Jakarta.

Supriatna Tjahya,2000, Legitimasi Pemerintahan: Manajemen dan Organisasi Publik serta Manajemen Pemerintahan Daerah, CV. Maulana, Bandung.

Stikes. Renstra Tahun 2014-2015. Grut; STikes Karsa Husada. (Tidak Diterbitkan). masyarakat menjadi kurang percaya terhadap pelayanan yang diberikan oleh STIKes. 